\title{
Superstructure Analysis in News Stories-A Contrastive Study of Superstructure in VOA, BBC, and NPR News
}

\author{
Xinyue Zhang ${ }^{1}$, Yujiao Pan $^{2} \&$ Mengmeng Zhang ${ }^{2}$ \\ ${ }^{1}$ School of International Education, Dalian University of Technology, China \\ ${ }^{2}$ School of Foreign Languages, Dalian University of Technology, China \\ Correspondence: Yujiao Pan, School of Foreign Languages, Dalian University of Technology, China. E-mail: \\ 1295097218@qq.com
}

Received: July 10, 2014 Accepted: August 21, 2014 Online Published: October 30, 2014

doi:10.5539/ass.v10n22p199 URL: http://dx.doi.org/10.5539/ass.v10n22p199

\begin{abstract}
In news discourse, it is necessary to conclude the general feature of news discourse. It is supposed that there is a standard structure or news schemata to organize the news report. As we all know that the beginning of the news is headline or lead, in the following, there are main event, comment, previous event, aftereffect, situation and so on. The author of this paper chose 60 pieces of news from VOA, BBC, and NPR. The author used news schemata to analyze each piece of news. The purpose of this paper is to find out whether the structure of news fits the schemata or not and further describe the writing features of each news station. Moreover, different news stations have different characteristics in writing styles. BBC news emphasizes the role of comment while reporting the event, but it pays little attention to introduce the situation or background information. VOA news has no distinct feature in comment and main event; however, it spends more words on introducing background information. There is one point the author wants to remind: though verbal reaction does not as important as other elements, BBC and NPR indeed contain this item; VOA news has no verbal reaction at all. VOA reporters do not prefer to quote the exact opinion from news actors. NPR prefers to pay more attention to main event, and pay little attention to aftereffect. From concluding news schemata, it is not only helpful to know reporting features of the stations, but also helpful to study news discourse in a more clear, systematic and interesting way.
\end{abstract}

Keywords: news discourse, radio news schemata, superstructure, VOA, BBC, NPR, discourse analysis

\section{Introduction}

Discourse analysis is a mixed branch of discipline, which develops from linguistics, anthropology, semiology, psychology and so on. It emerged in the early 1970s. In the first period of its development, a number of important studies published: Brown and Yule (1983), Stubbs (1983) and Van Dijk (1983), among whom Van Dijk is an outstanding scholar for his effort and contribution in discourse analysis. In the process of its history, a great number of new and emerging research fields have been of benefit to the systematic analysis of the linguistic features and patterns. Many researchers have expanded the scope of discourse analysis, ranging from fixed and written form to conversation under various circumstances.

\subsection{Language Data}

This paper concentrates on the development of discourse analysis and its relevant theories; it takes news analysis as the example. Moreover, the author chooses 60 pieces of news from VOA, BBC and NPR to conclude the feature of news.

\subsection{News Analysis}

It will be rather difficult to cover the whole range of discourse analysis in a single article, for it is a complicated and broad discipline. The author therefore focuses on news discourse. From analyzing that news, we might get the rule or pattern of news writing, which helps the writers and readers further and better understand the situation. For example, people want to 'situate' medical discourse in a hospital, educational discourse or conversations in schools or universities, and political discourses in parliament. After getting the context model, when the reader reads a story about domestic violence, his understanding of such a story forms a model of that event. In this way, the reader builds a bridge between knowledge and news models. 


\subsection{Purpose}

The main purpose of this paper is that from news analysis of those 60 pieces of news, finding news schemata and deciding which element plays a more important role in news writing. On one hand, such a schemata helps the journalists to finish the news writing in the first time, on the other hand, it helps the readers to understand the news as quick as possible, for they have already had a news model in their minds.

\subsection{Method}

The author collected 20 pieces of news from each radio station (VOA. BBC, NPR). Those 60 pieces of news are all chosen stochastically. For each piece of news, the author researched its pattern from the macrostructure angle. As for the research part, the author got the percentage of each element over the whole passage. In this way, it is easy to find which kind of writing pattern the journalists prefer.

\section{The Literature Review}

\subsection{Discourse Analysis}

Discourse analysis, merged in the early 1970s. The modern history of written discourse is perhaps span 40-50-year. In the first period of its development, a number of important studies published: Brown and Yule (1983), Stubbs (1983) and Van Dijk (1983). Discourse analysis is the field, which deals with the organization of texts, ways in which parts of texts are connected, and the devices used for achieving textual structure.

Discourse analysis is a multidisciplinary field. It draws form anthropology, applied linguistics, autonomous linguistics, English, education, law, psychology, rhetorical studies, sociology and technical communications. These approaches have a common concern: they stress the need to see language as a dynamic, social, interactive phenomenon---whether between speaker and listener, or writer and reader

\subsection{Macro-structure}

Not all-textual analysis starts with small units and works, some approaches aim to make very general statements about macrostructure of a text. For example, psycholinguistics attempts to analyze narratives into schematic outlines that represent the elements in a story that readers remember. These schemata are called 'story-grammars'. (David crystal. the Cambridge encyclopedia of language. Cambridge university press, n. d., p. 119). In one such approach, simple narratives are analyzed into four components: setting, theme, plot, and resolution. The setting has three components: the characters, a location, and a time. The theme consists of an event and a goal. The plot consists of various episodes, each with its own goal and outcome. Using distinctions of this kind, simple stories are analyzed into these components, to see whether the same kind of structure can be found in piece of news.

As reducing the complexity of such environments in complicated stories, they deal with news report or novel in the same way: they use the general category of a schema, representing local information at macro-level. Therefore, they summarize the social environment at the macro-level of their context models. Van Dijk (2005) states that it is in this way that they are able to control the local situation variables and their information, and control discourse at the same time at the micro and macro levels. And the reduced situational information not only is suitable for the constraints of context models, but fit the semantic macrostructures of discourse, which are necessary to produce globally coherent discourse. Thus the macro-level information in the context models well controls both the local and the global appropriateness of the discourse.

There are two different models of the same structure --- a micro and a macro model. As for the current situation, language users may foreground or background the global level information. This level-dependent processing of situational information is not limited to contexts, but also well known in discourse processing itself: language users are able to express and understand meaning at various levels between micro and macro structures (Van Dijk, 1980)

\subsection{News Discourse}

Among various discourse analyses, Dutch scholar----Van Dijk's study of news discourse has his peculiar feature. He believes that discourse is a kind of social control power, which represents the willpower of authority, and reflects special power structure. Such as developed countries and developing countries, celebrities and common citizens, parents and children, teachers and students, white men and black men. The people who control and spread discourse are news journalists, writers, artists and scholars. These people are called "symbolic elites". The powerful people are entitled to control all kinds of discourse, while common people are only able to control daily conversation. The aim of Van Dijk's study is to observe in what ways the powerful people implement, express, describe or conceal their ambition through context and discourse. In particular, he pays much attention to the role of ideology; he had made amounts of media discourse surveys, such as news report, TV program, and 
advertisement. His purpose is to illustrate how western authorities control the form and content of discourse, and further control the belief and ideology of society.

Since from 1980s, Van Dijk used discourse analysis to study news report, and made new progress. In his opinion, to vast majority people, news report is the most common type of written discourse, and news text plays an important role in mass communication. Therefore, making discourse analysis to news is not only helpful to understand other media discourse, but also helpful to know social function of mass communication. Firstly, he analyzed the internal structure of news discourse; the idea of this analysis is derived from demonology. The same to other discourse, news report also has its systematic structure; he called it "superstructure" which consists of conventional categories. It is supposed that superstructure is a tall building, conventional categories is the rooms of the building. Though each room is different, the basic architectural principles are the same. Therefore, it is quite easy to distinguish which are news reports, which are not, because they have the same form.

Journalists have to deal with those conventional categories, for example, in order to fill in verbal reactions, reporters need to interview important news actors: in order to introduce background, reporters have to refer to historical literature or cyclopedia. In the process, the journalists add their emotion and ideology to the report. For example, whose opinion should be quoted, whose should not, in what forms quote the verbal reactions. These elements control the news text and news orientation.

Like many other discourse genres, making extensive use of reference to the places and periods of events, these also require conceptualization about the place and time frame of the speaker or writer.

Some of this global information may be more accessible than other information: We usually have direct access to the information about the city or country we are in. People probably do have Macro representations of agency in context models not only feature identity, but also information about roles and relationships for collective agents. Thus, the newspaper may discursively self-represent itself as opponent of the government or as critic of industrial environmental practices, as would typically be the case in editorials.

This paper tries to see whether the news, which the author chose, is belonging to the radio news schema. The notion of schema implies the consideration of sociocultural conventions that exist around texts or discoursal units, and it should be taken into account when measuring the readers' comprehension.

There are two elements affected reading comprehension: one is reader' prior knowledge; another is the notion of the reader as an active subject whose mental background is activated in every act of learning. In top-down reading comprehension models, readers are envisaged as interacting with texts, in that they interpret the text and infer its meaning with the help of their own knowledge, so that every act of reading is different even if the text is the same.

\section{The Examples of Macrostructure}

The term of macrostructure was firstly put forward by Konstanz. Van Dijk had said that German linguist Bierwisch used this term in 1965. Another term opposed to macrostructure is microstructure. Microstructure is the basic proposition to describe the detailed event or state. The process of transform microstructure to macrostructure is shrink several basic proposition into more general proposition. For example, "the man walked to his car, got in and drove off" can be shrunk into "the man drove off". Because readers want to know that the man drove off, not the process how he drove off. Generally speaking, there are three kinds of macro rules: deletion rule, generalization rule and construction rule. In the following, the author will give readers some examples for each rule:

a) Deletion

The above example belongs to this category

b) Generalization

"My daughter likes kittens and puppies" can be substituted by "my daughter likes small pets."

c) Construction

"Jack went to the station, bought a ticket, walked to the platform and got on board the train" can be changed by "Jack took a train."

Those are short sentences, for paragraphs, three rules can be used at the same time. Here is an example of the paragraph:

Yesterday afternoon Mary was at her bank round the corner. Suddenly, one of the clients took a gun out of his pocket. He shot a couple of times in the air and then aimed at the cashier. He said that he wanted all the cash she 
had in her desk. She was frightened and gave the money to him. Then he ran away. The police have not ye caught him.

The first round:

Yesterday afternoon Mary was at her bank round the corner. A client threatened the cashier. He wanted all her cash. She gave in and he escaped.

Here" shot a couple of times in the air and then aimed at the cashier" using construction rule. Therefore, the sentence is substituted by "threatening"

The second round:

Yesterday morning at our bank, a client threatened the cahier. He wanted all her money. He succeeded.

The third round:

Somebody robbed our bank yesterday.

In the first round, construction rule was used, that is why the macrostructures "a client threatened the cashier" and "she gave in" come out. The proposition "he wanted all her money" using deletion rules.

It is certain that different people have different ways to deal with macro rules and get different result. Generally speaking, each way is done under these three rules.

In news analysis, similar method is used. The difference is that in news schema, each sentence is categorized into more general element.

\section{Radio News Schemata}

\subsection{Introduction of Radio News Schema}

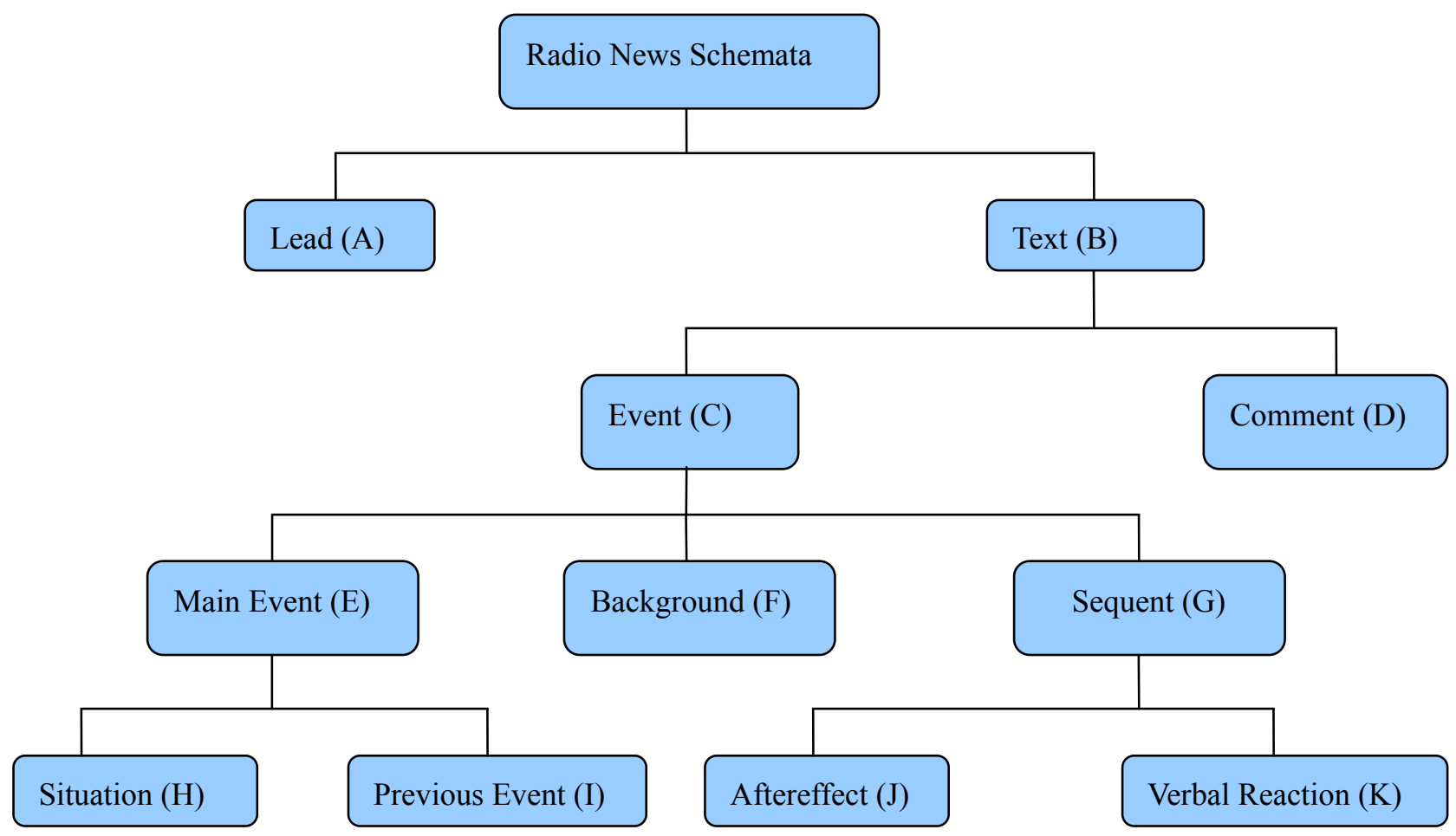

Figure 1. Radio news schemata

As a discipline of discourse analysis, news analysis is the best example to illustrate macrostructure. In news report, the journalist will have to produce the news in the first time; one feature of news is its prompt in report. Therefore, the journalists should have certain rules or patterns to follow. In this way, they do not need to create new style or way of writing in the spot. Different from novels and prose, readers care little about whether the news has the polished language or not, they really care about what kind of information the news confers. If some patterns of news report are concluded, on one hand, it is convenient for reporters to organize the text of news. On 
the other hand, with the help of background information and common sense, it is easier for readers to understand the event, both of national event and international event.

It is certain that different radio stations and newspaper offices have different writing styles. For example, some stations pay more attention to the relationship between many events; others concentrate on verbal reaction to increase reliability. Thereby, the author chose 60 pieces of news from 3 different radio stations. (VOA, BBC, NPR). All of them are famous foreign stations. It is hoped that from analyzing their news, the author could find the radio news schema, to prove whether or not fit Xiongxueliang's schema. Of course, it is impossible that each piece of news includes every element, the purpose of this paper is to find out which elements are frequently used, which elements play the important role in composing the news.

The author chose 60 pieces of news from 200 pieces of news to make the research more reasonable. All the news is from January to March 2006. There is one point to emphasize: all 60 pieces of news are random samples.

\subsection{Elements of News Schemata}

There are seven parts of the news schema: lead, main event, comment, situation, previous event, caused result and verbal reaction.

Lead is a necessary part of news schema. Of course not all the news has lead. The function of lead is generalizing the news content so that readers will know the central idea easily. It is a good way to attract readers' attention and interest. The function of the lead is to tell the readers what had happened in one or two simple sentences. Judging from the lead, readers are able to decide whether this piece of news is worth reading or not. Therefore, many people have the habit of scanning the news leads, they only curious about the events, not the detail of the events. To some extent, this is timesaving. After reading the lead line, other readers care about the exact detail of the matter.

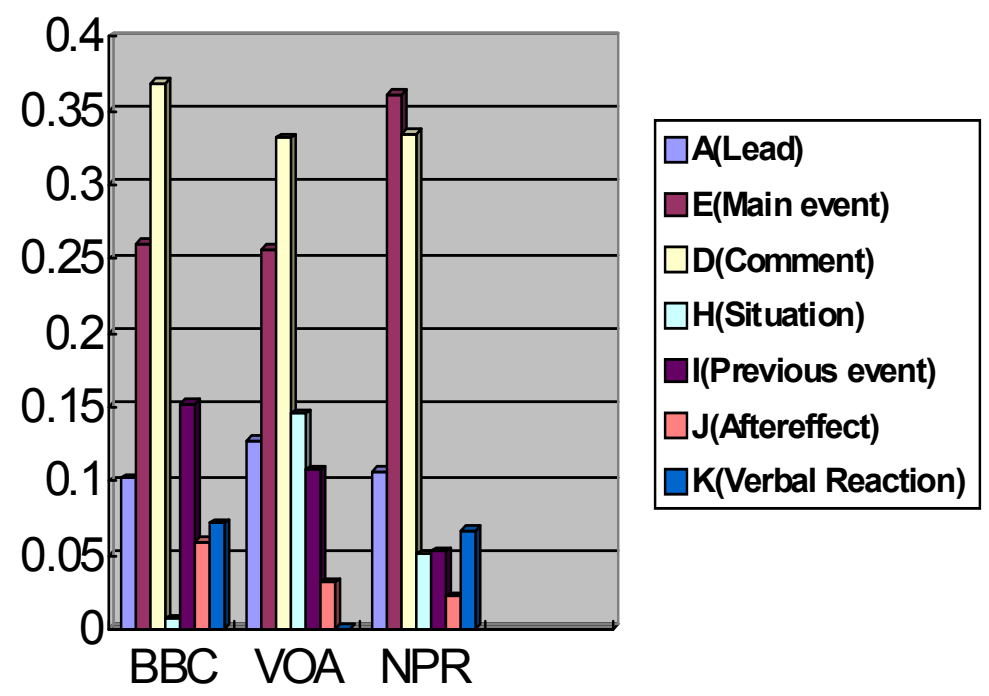

Figure 2.

News schema contains comment on the news background and news itself. In majority situation, background situation appears in the last part of the news, which is after reporting the main event. Background situation includes historical reason of the present event. In some cases, it is difficult to classify background and previous event. Reporters often remind readers what had happened by presenting previous event.

Aftereffect frequently appears in the news schema. For social and political events, the serious level of aftereffect determines their news value. Discussion towards real or potential sequence may increase causal coherence to the report. Sometimes, aftereffect is more important than event itself.

In most cases, after reporting significant news event, important participants and prestigious politicians are invited to present opinions on the event. The reason for making such arrangement is simple: journalists have the opportunity to expound impersonal facts, which do not necessarily equal to their own opinion, because these opinions are expressed as they are. Reporters only record what participants said. However, it may not objective 
to choose what kinds of people to make comment and publish which parts of their opinions.

Though many editors and journalists agree that facts should not mix with opinion, comment indeed exist in the news report, sometimes in indirect form. Comment contains appraise and prediction. Appraise on the value and meaning of the event; prediction to the political aftereffect and other aftereffect, or potential sequent. It is not enough if the passage only has lead line and main event, because if the reporters write everything of their own, it is not persuasive for it will evitable add the reporters' opinion. So the better way is quote others' words in the passage, using others' opinion to increase reliability as well as reduce the responsibility of conveying false information. On the condition that the news deliver wrong information, perhaps news station has no intention to do that, it is coincidence. The station has enough reason to avoid shouldering responsibility.

It can make the best of both worlds. From the study of 60 pieces of news, it is concluded that all of those 60 passages have the comment, the comment from the officers, police, government and United Nations

\section{Results and Discussion}

\subsection{Analysis of the Statistics from News Study}

Looking at the graph, it is obvious that $\mathrm{E}$ (Main event) and D (comment) have the highest percentages in the graph. Compared with two other stations, $\mathrm{BBC}$ news station has comment element in the highest level. It is proved that in reporting news, $\mathrm{BBC}$ news pays more attention on comment, comment from reporter, authority, and official. Meanwhile, the percentage of situation of BBC news is very small. VOA news has the highest level of situation element. It means that VOA spends more words on the introduction of situation, which includes historical background, present international surrounding. By contrast, VOA news has no oral reflection item, though BBC and NPR news have very low percentage of K item, they indeed have this item. All of 20 pieces of VOA news do not have oral reflection from participants. Therefore, there is no blue mark in the graph. NPR news focuses on reporting main event,

From the graph, it is quite easy to know the reporting features of each station. All of these stations have their own focuses and characteristics.

\subsection{Analysis of News}

\subsubsection{Examples from BBC News}

(BBC 2006-03-01)

(A-1) At least 18 people have been killed in continuing violence in Iraq.

(E-2) The heaviest casualty has come in motor attack of a Shiite/in southern Baghdad.

(D-3) Meanwhile, for the second time in a week, insurgence has attacked the Shiite muslin shrine.

(E-4) A bomb exploded at the/shrine in the southern city of Basra. John brand reports from Baghdad

(D-5) The motor-attack at door inside Baghdad/marked the tide of sectarian violence which is plaguing Iraq.

(I-6) A train was parked into a shrine enclave within a mainly Shiite neighborhood.

(D-7) It was just one of a series of acts of violence across the country.

(I-8) In Bakuba two men were killed in a drive by shooting as they're playing football, several children with them were injured.

(I-9) And in Basra, a bomb exploded in a Shiite shrine.

(J-10) The device detonated prematurely injured the men who planted it and failing to damage intended targets.

(D-11) But despite another dark day in Iraq, there has been a glimmer of light on the political front.

(D-12) The biggest Shiite bloc said they had prepared to consider resuming negotiation to form new government.

In the news, A, E, D, I, J represent (1). (2-4). (3-5-7-11-12). (6-8-9). (10). This passage contains five elements of schema. It is obvious that lead, event and comment are the basic elements; almost every passage contains those elements. The author classified the third, the fifth, the seventh, the eleventh and the twelfth sentences into comment group. Sometimes, it is acceptable for reporters to air their opinions because their comment is based on research and interview.

In the lead, reporter should state clearly $5 \mathrm{~W}$ and $1 \mathrm{H}$, which is what, happened, when it happened, where did it happen, who did it involve and how did it happen. For this lead, the reporter states many elements: who (18 people), what (have been killed), when (---), where (in Iraq), why (---). There is a tendency that the method of reporting has been simplified, not all the items are included in the lead. It depends on the situation. 
(1) Lead: 18 people were killed

(2) Comment: motor attack was the heaviest casualty.

(3/4) Main event: introduce the violence.

(5) Comment: comment on the motor attack.

(6) Previous event: the detail of the attack.

(7) Comment: motor attack is just one of the violence.

(8/9) Previous event: the casualty of the attack.

(10) Aftereffect: the device injured a man.

(11) Comment: reporter's comment on Iraq situation.

(12) Comment: Shiite blot prepared to form new government.

In this passage, there is no direct comment from authority. The case is that the reporter told the readers when and where a series of violence happened, of course he got the statistics from the authority, but he did not use others' words.

(BBC 2006-01-25)

(A-1) The Ford Motor Company has unveiled plans to lay off up to 30,000 workers and shut down 14 plants in North America as part of an attempt to turn around its loss-making operation.

(E-2) The cuts will hit nearly a quarter of Ford's North American workforce.

(D-3) The Chairman Bill Ford has described the restructuring plan as a last resort.

(D-4) Our business correspondent Th.L. said the US car industry is facing huge competition from Asia.

(I-5) For years and years, they had everything in their own way.

(I-6) They dominated their home market.

(I-7) They also exported cars around the world.

(I-8) American cars were the best.

(D-9) That simply isn't the case anymore.

(H-10) And the Japanese have invested time and money into building cars that people want to buy.

(J-11) And gradually, they've been making inroads into the US market.

(E-12) And what's really sparked the thing off now is that the American carmakers were focusing on building big, powerful off-road cars.

(H-13) But then with rising oil prices, the cost running those went up, people became a little less enthusiastic about them.

(J-14) And they've started to find that the products the Japanese offering have more appeal.

A (1), D (3.4.9), J (2.11.14), I (5.6.7.8) H (10.13) E (12)

In the lead, reporter presents many items: who (the ford motor company), what (lay off workers and shut down plants.), when (---), where (North America), why (turn around its loss-making operation).

(2) Caused result: the plan will hit nearly a quarter of its workforce.

(3/4) Comment: get affirmation from two person, chairman and correspondent.

$(5 / 6 / 7 / 8)$ previous situation

(9) Comment: the situation changed

(10) Situation: USA facing competition from Japan.

(11) Previous event: Japanese cars inroad to USA

(12) Main event: the disadvantage of US cars

(13) Situation: external reasons

(14) Aftereffect: the sequence of competition.

This news includes more elements than others: lead, main event, comment, previous event, aftereffect, and 
situation. There is no oral reflection only. In fact, the vast majority of news does not have this item, except the report need to record the spot situation vividly. The passage focuses on the reason why Ford Motor Company failed in the competition against Japan. It recalls the history, states the present and points out the weak points of Ford. Therefore, the news has more words on previous event and situation.

(BBC 2006-01-01)

(D-1) The head of the United Nations Refugee Agency Antonio Guterres has expressed shock at the loss of life during an operation by Egyptian police to remove Sudanese migrants from a makeshift camp in Cairo.

(E-2) Egyptian government says at least 20 people are known to have died.

(D-3) As Bethany Bell reports from Cairo, the Egyptian Foreign Ministry stressed that attempts to end the protest peacefully had failed.

(D-4) The Egyptian Foreign Ministry said that it had done all it could to trying convince the Sudanese to end their three-month long protest peacefully.

(E-5) But it said the migrants had rejected all offers and it has become necessary to end the protest.

(I-6) Earlier on Friday, thousands of Egyptian riot police moved in with water-cannon and truncheons to break up the camp where up to 3,000 Sudanese have been living.

(E-7) The protesters have been demanding to be resettled in the west, something the UNHCR said it was unable to guarantee.

D (1.3.4) E (2.5) I (6)

This passage is relatively simple and only has three elements; particularly there is no lead. The first sentence said the authority expresses shock at the loss of people.

(1) Comment: UN comment on the event.

(2) Main event: What had happened?

(3) Comment: Egyptian authority's comment.

(4) Comment: Further illustrate the comment.

(5) Main event: Migrant rejected the request.

(6) Previous situation: Egyptian police try to prevent them.

(7) Main event: the authority could not guarantee their demand.

There are mainly two types of comment: first, reporter states clearly the name and occupation of reviewer. Such as "the head of the UN refugee agency Antonio Guterres", "the president-elect of Bolicia Evo Morales", "prime minister Ariel Sharon" and so on. Second, without stating name, "UN officials", "Turkey's health minister", "the Libyan government".

\subsubsection{Examples from NPR News}

(NPR 2006-03-1)

(D-1) India's Prime Minister has said talks with the United States about an agreement that would end the international moratorium on exporting nuclear technology to New Delhi have been difficult.

(D-2) The issue is expected to dominate this week's visit to India by President Bush. NPR's Philip Reeves reports from New Delhi.

(E-3) The proposed deal requires India to separate its civilian nuclear plants from its military ones.

(E-4) The civilian instillations will then be opened to inspection by the UN's monitoring body, the IAEA.

(H-5) Yet deciding which plants should be listed as civilian and which should remain secret, has proved a sticking point.

(D-6) The Indian prime minister today sought to quell concerns in India that the agreement intended to curtail India's nuclear weapons program.

(D-7) He told parliamentarians that his country's nuclear deterrent would not be compromised, now or in the future, and nor would research and development in that field.

(D-8) Both sides hope to seal a deal in time for President Bush's visit, which begins Wednesday, though a final agreement will ultimately need approval from the US Congress and the Indian Parliament. Philip Reeves, NPR 
News, New Delhi.

D (1.2.6.7.8) E (3.4) H (5)

(1) Comment: India's attitude towards talks with the US.

(2) Comment: expectation to this week's visit.

(3/4) Main event: requirement to India.

(5) Situation: the sticking point.

(6/7) Comment: India's prime minister's opinion to the agreement.

(8) Comment: the expectation to Bush's visit.

There is no lead in this passage; the first sentence is prime minister's comment on the talks. Reporter uses authority's opinion instead of writing lead. It is obvious that comment appears 5 times; therefore, the feature of this news is stating both sides' opinions and attitudes to the issue. It includes US's requirement to India and India's reaction. Once more, it proved that in order to make news sound more reliable, writer prefers to use other's opinion instead of have a comment of his own.

(NPR 2006-01-31)

(A-1) 72 miners have survived a fire at a mine in the Canadian province of Saskatchewan.

(E-2) As C.M reports, the miners retreated to emergency safety rooms and waited out the blaze.

(E-3) The miners came to the surface a day after fire broke out in the mine about 130 miles northeast of Regina, the provincial capital. (E-4) The workers retreated to what they described as safe rooms, which are sealed off from the rest of the mine.

(H-5) These rooms are equipped with food, water, beds, blankets and enough oxygen to last 36 hours.

(I-6) They were trapped in these rooms since early Sunday morning when fire broke out in polyethylene piping more than half a mile beneath the surface.

(D-7) A mine official says the pipe burned like a wick.

(E-8) The miners managed to avoid both the flames and the toxic smoke, which made firefighting a problem.

(H-9) Officials had to wait for the fumes to clear before giving miners the okay to leave the rooms and walk to the surface.

(D-10) There are no reported injuries among the miners.

(H-11) What caused the fire is under investigation.

(H-12) The miners harvest potash, which is used as a main ingredient in fertilizer and other agricultural products. For NPR News, I'm C.M.

A (1) E (2.3.4.8) H (5.9.11.12) I (6) D (7.10)

(1) Lead: 72 miners have survived in a fire.

(2) Main event: the miners are sent to safety rooms.

(3/4) Main event: the present condition of miners.

(5) Situation: their living condition

(6) Previous event: since Sunday morning they were there.

(7) Comment: police described the burnt.

(8) Main event: what had happened in the spot?

(9) Situation: situation in the spot.

(10) Comment: no reported injuries.

(11) Situation: the reason of fire is under investigation.

(12) Comment: introduction of potash.

This passage has 5 elements of news schema, the first sentence is lead, and then describes the main event, at the same time, give readers detail information about the fire. Therefore, this news has the normal order: lead, main event, previous event and comment from different sides. 


\subsubsection{Example from VOA News}

(VOA 2006-03-25)

(A-1) Pakistan has accused Afghan forces of killing sixteen Pakistani civilians earlier this week.

(D-2) A spokeswoman for Pakistan's foreign minister said ministry officials met with the Afghan ambassador and protested the killings. (D-3) She said Pakistan is demanding an independent investigation of the incident.

(E-4) An Afghan commander had said his soldiers killed 16 suspected militants after they crossed the border from Pakistan on Tuesday.

(E-5) Pakistani officials say the victims were civilians traveling to a religious observance.

(E-6) Afghan officials say a police officer shot and killed a local police chief Thursday in Southern Afghanistan.

(E-7) A local official says a police guard shot and killed his supervisor, the police chief in the Musa Qala area of Helmand province.

(E-8) Other policemen then shot the guard.

(E-9) In the Afghan province of Uruzgan, Afghan soldiers aided by coalition forces killed 6 suspected Taliban rebels.

(E-9) Coalition forces say the target was a Taliban command group. The forces also said they seized materials for making bombs.

A (1) D (2.3.10.11) E (4.5.6.7.8.9)

(1) Lead: the reason why Pakistan accused of Afghan forces.

(2) Comment: Pakistan official protested the killings.

(3) Comment: Pakistan demanded the investigation of the incident.

(4) Main event: Afghan soldiers have killed 16 suspected militants.

(5) Main event: the victims were civilians.

(6/7/8/9) Main event: the detail of the incident.

(10/11) Comment: comment made by coalition forces.

There are only lead, main event and comment in the passage. Most content using official's opinion from sides, even the event part, and the reporter also used official's opinion to describe the detail of the event. Therefore, the schema of this passage is quite simple, only three elements.

\section{Conclusion}

From discourse analysis angle, this paper introduces to readers about the theories in this field, which includes discourse analysis, superstructure, macrostructure and examples of macro rules. All the above theories are the root of news discourse, for news discourse is a perspective of discourse analysis. The emphasis of this paper is analyzing 60 pieces of news by the author. It is certain that the conclusion of research is not that objective, because different people have different standards to the same passage. For example, to the same sentence, some people regard it as comment, but others treat it as main event. In spite of it, by analyzing the radio news schemata, rules in writing and organizing news can be found, therefore, it is convenient for both reporters and readers, for reporters have a clear mind how to write the news, that is put the most important information at the beginning; and readers could easily understand what kind of information the reporters want to confer.

After having a study on that news, the author finds that not all the journalists are objective about the event, some use emotional words, such as "Egyptian riot police", "defiant crowds", "iron-fisted incumbent" and so on, those words imply the author's emotion, his likeness or hatred towards certain countries and some people.

Each news station has their characteristics. BBC news prefers to quote others' opinions to prove that those words and facts are true, for readers can know who have said that. Reporters do not make up facts. VOA news pays more attention to the introduction of the background information. The reporter prefers to connect this event with other relevant information. In this way, the readers will know more detail about some hot issues. Meanwhile, NPR news stresses main event itself. Instead of quoting others' words, NPR journalists prefer to tell readers what have happened in some countries. It is obvious that the main event is based on interviewing, interviewing authority, participants, and eyewitnesses. In most cases, one piece of news only contains several items; some even only have three items. However, finding common schemata of radio news is helpful to the study of news pattern and news value. 


\section{References}

Bell, A., \& Garrett, P. (1998). Approaches to Media Discourse. Oxford: Balckwell.

Berger, A. A. (2000). Media and Communication Research Method. California: Sage Publications, Ltd.

Bierwisch, M. (1970). Poetics and Linguistics. In D. Freeman (Ed.), Linguistics and Literary Style (pp. 96-115). New York, NY: Holt, Rinehart \& Winston. http://dx.doi.org/10.1515/9783111350219

Brown, G., \& Yule, G. (1983). Discourse and Analysis. Cambridge: Cambridge University Press. http://dx.doi.org $/ 10.1017 / \mathrm{CBO} 9780511805226$

Cook, A. E., Limber, J. E., \& O'Brien, E. J. (2001). Situation-based context and the availability of predictive inferences. Journal of memory and language, 44, 220-234. http://dx.doi.org/10.1006/jmla.2000.2744

Fairclough, N. (1995). Media Discourse. London: Edward Arnold.

Fowler, R. (1991). Language in the News Discourse and Ideology in the Press. London: Rooutledge.

Fuchs. (2011). Foundations of Critical Media and Information Studies. London: Routledge.

Graddol, D., \& Boyd-Barrett, O. (Eds.). (1994). Media Texts: Authors and Readers. Clevedon: Multilingua 1 Matters Ltd.

Harris, G., \& Spark, D. (1993). Practical Newspaper Reporting. Oxford: Focal Press.

Hong, F. (2002). Macrostructure and microstructure of news discourse. Tsinghua Science and Technology (Philosophy and Social Science), S1.

Labov, W. (1972). Sociolinguistic Patterns. Philadelphia: University of Pennsylvania Press.

Li, B. (2003). The Perspective of Semiotics. Shanghai: Fudan University Press.

Liu, R. Q. (2002). An Introduction to Discourse Pragmatics. Beijing: Foreign Language Teaching and Research Press.

Nicholas, B. N. (1993). Newspaper Language. Oxford: Focal Press.

Piazza, R. (1999). Dramatic discourse approached from a conversational analysis perspective: Catherine Hayes's Skirmishes and other contemporary plays. Journal of pragmatics, 31, 1001-1023. http://dx.doi.org/10. 1016/S0378-2166(99)00050-8

Rayner, P., Wall, P., \& Kruger, S. (2001). Media Studies: The Essential Introduction. London: Routledge.

Robert, B., \& Kaplan, W. G. (2002). A modern history of written discourse analysis. Journal of second language writing, 11, 191-223. http://dx.doi.org/10.1016/S1060-3743(02)00085-1

Schank, R., \& Burstein, M. (1985). Artificial Intelligence: Modeling Memory for Language Understanding. In T. van Dijk (Ed.), Handbook of Discourse Analysis (Vol. 1(C)).

Van Dijk, T. (1980). Macrostructures. New Jersey: Lawrence Erlbaum Associates Publishers.

Van Dijk, T. (1988). News as Discourse. New Jersey: Lawrence Erlbaum Associates Publishers.

Van Dijk, T. (1995). Ideological Analysis as discourse Analysis. In C. Schaffner, \& A. L. Wendern (Eds.), Language and Pace. Dartmouth: Alder Shot.

Watson, J., \& Hill, A. (2000). Dictionary of Media and Communication Studies. London: Arnold.

Wodak et al. (2008). Critical Discourse Analysis: History, Agenda, Theory, and Methodology. In R. Wodak, \& M. Meyer (Eds.), Methods for Critical Discourse Analysis (2nd Revised ed., pp. 1-33). London: Sage.

Xiong, X. L. (1999). An Introduction to Cognitive Pragmatics. Shanghai: Shanghai Foreign Language Teaching Press.

Zelizer et al. (2002). How bias shapes the news? Challenging the New York Times' status as a newspaper of record on the Middle East. Journalism, 3(3), 283-307. http://dx.doi.org/10.1177/146488490200300305

\section{Copyrights}

Copyright for this article is retained by the author(s), with first publication rights granted to the journal.

This is an open-access article distributed under the terms and conditions of the Creative Commons Attribution license (http://creativecommons.org/licenses/by/3.0/). 